\title{
Programme aids developing world
}

\section{Washington}

A US-BASED centre hopes to help developing countries take advantage of advances in agricultural biotechnology with the support of private companies and foundations that want to stimulate that technology.

Last month, the International Service for the Acquisition of Agri-biotech Applications (ISAAA) announced its home for the next five years would be at Cornell University in Ithaca, New York. ISAAA intends to help farmers increase yields and reduce their dependence on pesticides in a handful of countries that are best prepared to take advantage of the new technologies.

At present those farmers lack the money, technical skills and infrastructure to make use of this technology, which is becoming increasingly proprietary. What ISAAA hopes to do is tap into that extensive knowledge, now held mostly by private industry, and transfer it to developing countries without disrupting the way agriculture is carried out in those countries.

"That's the beauty of biotechnology", says Robert Fraley, who is director of plant science technology at Monsanto Company and a member of ISAAA's board of directors. At the same time biotechnology offers farmers the latest technology, he says, "you're providing it in a traditional seed package" that does not require any change in farming practices.

Previous efforts to transfer technology to developing countries have lacked sufficient people, technology and money in those countries. The models also have relied on laboratory-based initiatives between universities rather than people on the front lines. In contrast, ISSAA will invest not in laboratory facilities but rather in transferring tested technologies to those who can use them.

ISAAA has raised more than $\$ 4$ million in almost 10 months of operation, but David Altman, ISAAA's president and executive director, says it will need almost three times that amount to be fully operational. ISAAA also has found financial backers for two projects in Mexico and Taiwan.

The service plans to have branches around the world to help its staff learn about proprietary technology in those regions. In addition to its AmeriCenter at Cornell University, Altman hopes by next year to open a EuroCenter in Norwich, United Kingdom. Plans also are afoot for an AsiaCenter in Japan, as well as locating staff in Africa, Asia and Latin America.

ISAAA will concentrate on 10 target countries within Asia, Latin America and the Middle East/Africa - places that ISAAA feels have both the capability and political will to implement agricultural programmes in biotechnology, and where the chances for success are greatest. "We're not interested in creating a United $\mathrm{Na}$ - tions, we're interested in moving the process forward", he explains. It will also confine itself to applications that have been tested in industrialized countries and where field testing in the developing country can begin within five years.

Initially, ISAAA will focus on plant biotechnology applications in the areas of tissue culture, diagnostics and transgenic plants. Altman says that he favours projects that help poorer farmers to grow non-commercial crops, in particular vegetatively propagated and open-pollinated fruit and vegetables. Other projects will focus on forestry and the use of micropropagátion techniques to develop tropical tree species that will contribute to biodiversity and which are difficult to propagate through seed.

ISAAA has begun collaborative projects in Mexico and Taiwan and will soon begin a third with Costa Rica. Another 30 or so project proposals are in the pipeline. The Taiwanese project, with money from the US Agency for International Development, involves scientists from Washington State University and the Asian Vegetable Research and Development Center in Taiwan working together on a DNA probe to detect the presence of black rot in crucifers. The four-year Mexican project, which began last year with funding from the Rockefeller Foundation, hopes to extend proprietary virus-resistance technology, developed by Monsanto to protect North American potato varieties, to a locally grown Mexican variety of potato that accounts for 70 per cent of the national potato crop. It involves the Center for Advanced Research Studies (CINVESTAV) in Irapuato, Mexico, the Mexican Ministry of Agriculture and Water Resources and Monsanto.

The potato crop in Mexico, the country's fifth most important crop, suffers from serious losses due to viral diseases. Despite a $\$ 4$ million spray control programme, the reduction in annual yield can be as high as 25 per cent. Luis Herrara Estrella, head of genetic engineering at CINVESTAV, says that corn would have been a better target than potatoes because of its economic importance. But corn is also one of the most important commercial crops for agricultural companies in the United States. As a result, Estrella says, his centre had to pick a crop that was important to Mexico but one in which the transfer of technology "would not jeopardize the commercial interests of the company".

Robert Horsch of Monsanto says that the potato was chosen because the technology was available when the project was started two years. It was not possible at that time to genetically engineer corn, he says, and even today there are no products on the market in the United States.
Although Monsanto is commercializing the technology for North American potato varieties, it has waived its legal rights to the technology for use in the Mexican variety. "The potato project is an out-and-out donation of the technology", Horsch says. In the long run, however, Monsanto sees the project as an opportunity to build the contacts and infrastructure that some day will turn many of these countries into potential trading partners.

Mexican scientists being trained at Monsanto have already introduced the proprietary coat protein genes into the Mexican variety of potato, and Monsanto hopes to be able to conduct field tests of the virus-resistant potato in the United States by mid-summer. The scientists also are learning from Monsanto's experience with field-testing procedures and environmental pressure groups. In a related project, ISAAA is helping Mexican authorities to develop the infrastructure and regulatory biosafety procedures they need to test and introduce genetically engineered plant varieties.

Although good conventional plant breeding programmes also could improve crop yields in developing countries, biotechnology speeds up the process. At present it can take 12 years to produce a new wheat variety by conventional means, and seven or eight years for corn.

Diane Gershon

SEISMOLOGY

\section{Quake news quickest}

RESEARChers at the California Institute of Technology may not be able to predict the next earthquake, but once it happens they are usually the first to respond. Last week their experimental real-time earthquake information service passed a live test as Southern California was rocked by a earthquake measuring 6.0 on the Richter scale.

Caltech's Seismological Laboratory was able to broadcast seismological data on the quake within three to four minutes of the first shock. Data travelled from the university to a commercial radio pager network, then to receivers hooked up to computer terminals in the control rooms of its clients, five local utility companies and a railway company. The clients get information on the location, size, ground motion, amplitude and type of the earthquake, data they use to decide where to send repair trucks to look for damaged lines and service disruptions. Known as the Caltech-USGS [US Geological Survey] Broadcast of Earthquakes programme, the network has been in operation for about a year and a half and is the fastest in the country, according to its director, Hiroo Kanamori. 